did not find any relation between infiammatory activity and rheumatoid factor values.

The HLA-B27 associated arthropathies are typically seronegative disorders. We, however, carefully excluded patients with ankylosing spondylitis, reactive arthritis, and psoriatic arthritis, so these arthropathies could not have influenced the results.

The biological role of rheumatoid factors is not known. Although seropositivity at the onset of rheumatoid arthritis suggests a poorer prognosis, several studies have failed to detect a relation between IgM rheumatoid factor titres and disease activity. ${ }^{3-5}$ Finding an association of amyloid disease with seronegativity in adult rheumatoid arthritis may be interpreted in favour of some protective role of rheumatoid factors, at least with respect to the development of amyloid; or, more likely, seronegativity and the development of amyloid may be related to similar genetic factors.

This study was supported by the Sigrid Jusélius Foundation, Finland.

1 Maury CPJ. A review of reactive (secondary) amyloidosis and its pathogenesis.

Häyry P, von Willebrand E, Taskinen E, Höckerstedt $K$, Ahonen J, Eklund B. Is uremia suppressive in renal transplantation? Transplantation 1982;34:268-72. Masi AT, Maldonado-Cocco JA, Kaplan SB, Fergenbaum SL, Chandler RW Prospective study of the early course of rheumatoid arthritis in young adults : and identification of variables correlating with outcome. Semin Arthritis Rheum 1976;5:299-326.

4 Dixon JR, Pickup ME, Lowe JR, Hallett C, Lee MR, Wright V. Discriminatory indices of response of patients with rheumatoid arthritis treated with $D$ penicillamine. Ann Rheum Dis 1980;39:301-11.

5 Wernick R, Merryman P, Jaffe I, Ziff M. IgG and IgM rheumatoid factors in rheumatoid arthritis. Quantitative response to penicillamine therapy and rela1983;26:593-8.

(Accepted 11 fuly 1985)

Fourth Department of Medicine, University of Helsinki, SF-00170 Helsinki, Finland

C P J MAURY, $M D$, senior lecturer in medicine

A-M TEPPO, MSC, clinical chemist

Correspondence to: Dr Maury.

\section{Comparison of three physiotherapy regimens for hands with rheumatoid arthritis}

There have been few controlled comparisons of the various physiotherapy techniques for rheumatoid arthritis in the nands. A regimen of standard exercises supplemented by wax is available to most patients and general practitioners. We have compared this simple regimen with two, more elaborate forms of physiotherapy available in hospital departments.
Patients, methods, and results

Thirty inpatients with classical or definite rheumatoid arthritis (American Rheumatism Association criteria) affecting the hands were recruited. All had $\varrho$ pain and swelling of the hands and limitation of movement. Patients re- $C$ mained in hospital throughout the three week study period and existing drug $\widehat{\Omega}$ regimens and other procedures were continued unaltered. Intra-articular $\overline{\bar{J}}$ steroid injections were not allowed.

Patients were allocated at random to three groups. Group 1 received wax treatment followed by standard exercises for five days a week. The wax procedure entailed dipping the hands into melted wax 10 times, then wrapping them in greaseproof paper with a blanket which was left on for 20 minutes. Group 2 received ultrasound $\left(3 \mathrm{MHz}\right.$ at $250 \mathrm{~W} / \mathrm{cm}^{2}$ for six minutes per treatment) followed by standard exercises. Group 3 received ultrasound $\omega$ and faradic hand baths ( 15 minutes for each hand) followed by standard $\tau$ exercises.

Patients were assessed blindly by an independent observer before treat- $\frac{\bar{O}}{\bar{\omega}}$ ment and at weeks 1,2 , and 3 . Seven assessments were performed at each visit (grip strength, interphalangeal joint circumference, visual analogue scale for pain, articular index confined to the hand, range of movement in the fingers using a method analogous to Schoeber's test, time to dial a six figure \& telephone number, ability to perform daily activities).

The table gives the results. The groups were well matched initially and all showed significant improvement by week 3 (Wilcoxon's rank sum test: $0.01<\overrightarrow{.}$ $\mathrm{p}<0.05)$. About half the patients showed significant improvement after $\mathcal{O}$ only one week of treatment. Statistical comparison between groups was by $\partial$ Kruskal-Wallis one way analysis of variance by ranks. There was no signifi- 3 cant difference among treatments at any time for six of the seven assessments, iv but for activity score there was less improvement in group $3(\mathrm{p}<0.02)$. We 6 found no evidence of a difference in performance between dominant and non-dominant hands.

\section{Comment}

Although all three physiotherapy methods produced significant 0 improvement, six of the seven clinical assessments failed to disclose a significant difference between methods. We considered that the lack $\vec{N}$ of improvement in activity score observed with faradic hand baths $\bigcirc$ was not clinically important. Ultrasound or faradic hand baths appear to confer no advantage over the simpler wax treatment followed by standard exercises. This has important economic implications: ultrasound and faradic hand baths require referral to a hospital $\overrightarrow{0}$ physiotherapy department. Exercises may be supervised at home and of wax may be prescribed by general practitioners for patients who can use it safely, and these simple measures are likely to be just as effective in the treatment of rheumatoid arthritis of the hands.

(Accepted 11 fuly 1985)

Royal Bath Hospital, Harrogate, North Yorkshire

J HAWKES, MCSP, SRP, superintendent physiotherapist

G CARE, MCSP, research physiotherapist

J S DIXON, BSC, PHD, lecturer

H A BIRD, MD, FRCP, senior lecturer and honorary consultant rheumatologist

V WRIGHT, MD, FRCP, professor of rheumatology

Correspondence to: Dr H A Bird, Clinical Pharmacology Unit, Royal Bath Hospital, Harrogate, North Yorkshire HG1 2PS.

Mean results for each measurement for each treatment

\begin{tabular}{|c|c|c|c|c|c|}
\hline \multirow[b]{2}{*}{ Measurement } & \multirow[b]{2}{*}{ Treatment group } & \multicolumn{4}{|c|}{ Week } \\
\hline & & 0 & 1 & 2 & 3 \\
\hline Grip strength $(\mathrm{mm} \mathrm{Hg})$ & $\left\{\begin{array}{l}1 \\
2 \\
3\end{array}\right.$ & $\begin{array}{l}91 \\
66 \\
84\end{array}$ & $\begin{array}{l}99^{*} \\
81^{* *} \\
92^{*}\end{array}$ & $\begin{array}{r}111^{* *} \\
88^{* *} \\
95^{* *}\end{array}$ & $\begin{array}{r}111^{* *} \\
89^{* * *} \\
99^{* *}\end{array}$ \\
\hline Summed circumference of proximal interphalangeal joints (mm) & $\left\{\begin{array}{l}1 \\
2 \\
3\end{array}\right.$ & $\begin{array}{l}321 \\
314 \\
343\end{array}$ & $\begin{array}{l}314^{* *} \\
308 \\
335^{* *}\end{array}$ & $\begin{array}{l}310^{* *} \\
305^{* *} \\
331^{* *}\end{array}$ & $\begin{array}{l}310^{* *} \\
304^{*} \\
329^{* *}\end{array}$ \\
\hline Hand articular index & $\left\{\begin{array}{l}1 \\
2 \\
3\end{array}\right.$ & $\begin{array}{l}16 \\
13 \\
16\end{array}$ & $\begin{array}{l}11^{* *} \\
10^{*} \\
12^{* *}\end{array}$ & $\begin{array}{r}8^{* *} \\
7 * * \\
10^{* * *}\end{array}$ & $\begin{array}{r}6^{* *} \\
5^{* *} \\
10^{* *}\end{array}$ \\
\hline Pain score by visual analogue scale (mm) & $\left\{\begin{array}{l}1 \\
2 \\
3\end{array}\right.$ & $\begin{array}{l}67 \\
62 \\
71\end{array}$ & $\begin{array}{l}49 \\
47 \\
57^{*}\end{array}$ & $\begin{array}{l}39 \\
30^{*} \\
42^{* *}\end{array}$ & $\begin{array}{l}30^{*} \\
29 * \\
37^{* *}\end{array}$ \\
\hline Range of movement (mm) & $\left\{\begin{array}{l}1 \\
2 \\
3\end{array}\right.$ & $\begin{array}{l}57 \\
54 \\
66\end{array}$ & $=$ & $\bar{z}$ & $\begin{array}{l}90^{* *} \\
69^{*} \\
77\end{array}$ \\
\hline Timed task (s) & $\left\{\begin{array}{l}1 \\
2 \\
3\end{array}\right.$ & $\begin{array}{l}28 \\
30 \\
25\end{array}$ & $\begin{array}{l}23 \\
29 \\
21^{* *}\end{array}$ & $\begin{array}{l}20^{*} \\
27 \\
20^{* *}\end{array}$ & $\begin{array}{l}18^{*} \\
25^{*} \\
20^{*}\end{array}$ \\
\hline Activities score & $\left\{\begin{array}{l}1 \\
2 \\
3\end{array}\right.$ & $\begin{array}{l}6.6 \\
6.3 \\
7.7\end{array}$ & $\begin{array}{l}7 \cdot 8 \\
7 \cdot 7 \\
8 \cdot 2\end{array}$ & $\begin{array}{l}9 \cdot 4^{* *} \\
9 \cdot 1^{*} \\
9 \cdot 4^{*}\end{array}$ & $\begin{array}{c}10 \cdot 2^{* *} \\
10 \cdot 0^{*} \\
8.7\end{array}$ \\
\hline
\end{tabular}

Compared with baseline: *p $<0.05 ; *$ p $<0.01$ (Wilcoxon's rank sum test). 